\title{
Early neurodegeneration in R6/2 mice carrying the Huntington's disease mutation with a super-expanded CAG repeat, despite normal lifespan
}

\author{
Catherine $\operatorname{Kielar}^{1}$ and A. Jennifer Morton ${ }^{1 *}$ \\ Department of Physiology, Development and Neuroscience, University of Cambridge, \\ Downing Street, Cambridge CB2 3DY, UK
}

*Author for correspondence and reprint requests:
Professor Jenny Morton
Department of Physiology, Development and Neuroscience
University of Cambridge
Downing Street
Cambridge CB2 3DY
United Kingdom
Tel: +44 1223 334057
Fax: +44 1223333840
E-mail: ajm41@cam.ac.uk

Highlights

- Neurodegeneration and clinical signs are dissociated in HD mice with superlong (>550) CAG repeats

- HD mice with superlong CAG repeats have normal lifespans ( 2 years)

- Neurodegeneration is seen in HD mice with superlong CAG repeats by 20 weeks

- Extranuclear aggregates condense with age 


\begin{abstract}
The threshold of CAG repeat expansion in the HTT gene that causes HD is 36 CAG repeats, although 'superlong' expansions are found in individual neurons in post mortem brains.

Previously, we showed that, compared to mice with $<250$ CAG repeats, onset of disease in R6/2 mice carrying superlong ( $>440)$ CAG repeat expansions was delayed, and disease progression was slower. Inclusion pathology also differed from $250 \mathrm{CAG}$ repeat mice, being dominated by a novel kind of extranuclear neuronal inclusion (nENNI) that resembles a class of aggregate seen in patients with the adult onset form of HD. Here, we characterised neuropathology in R6/2 mice with $>400$ CAG repeats using light and electron microscopy. nENNIs were found with increased frequency and wider distribution with age. Some nENNIs appear to 'mature' as the disease develops, developing a multi-layered cored structure. Mice with superlong CAG repeats do not develop clinical signs until they are around 30-40 weeks of age, and they attain a normal life span ( $>2$ years). Nevertheless, they show brain atrophy and unequivocal neuron loss from the striatum and cortex by 22 weeks of age, an age at which similar pathology is seen in 250 CAG repeat mice. Since this time-point is 'end stage' for a 250 CAG mouse, but very far (at least 18 months) from end stage for a $>440 \mathrm{CAG}$ repeat mouse, our data confirm that the appearance of clinical signs, the formation of inclusions, and neurodegeneration are processes that progress independently. A better understanding of the relationship between CAG repeat length, neurodegenerative pathways, and clinical behavioural signs is essential, if we are to find strategies to delay or reverse the course of this disease.
\end{abstract}

Keywords: nENNI, NII, extranuclear inclusions, aggregation, huntingtin, ubiquitin, neurodegeneration, electron microscopy 


\section{Introduction}

Huntington's disease (HD) is a dominant genetic disorder caused by an unstable expansion of CAG repeats within the coding region of the HTT gene that encodes the protein huntingtin (Htt) [1]. HD patients display a complex spectrum of symptoms that typically include hyperkinetic involuntary movements, progressive dementia and personality changes that may include aggressiveness and paranoid psychosis [2,3].

The neuropathology of HD is characterised by early striatal neurodegeneration and the appearance of both neuronal intranuclear (NIIs) and extranuclear inclusions (ENNIs) [4,5]. The gradual atrophy of the caudate nucleus and putamen cortex [6] generally precedes the degeneration of other brain structures such as the cerebral cortex, globus pallidus, thalamus, subthalamic nucleus, substantia nigra, white matter and cerebellum (for review see [7]). In both patients and mice, normal Htt has a predominantly cytoplasmic distribution, whereas mutant Htt gradually aggregates into inclusions that likely appear before the onset of neurological symptoms [7-9]. Although it has been described in humans and animal models $[6,9,10]$ the relationship between neurodegeneration and aggregate pathology in humans is not well understood.

The role of inclusions in HD pathology remains unclear and somewhat controversial. Although inclusions have classically been considered neurotoxic [11-14] it is now clear that aggregates may also have a neuroprotective effect [15-22]. In our previous work, we suggested a consensus view, with aggregates being both neurotoxic and neuroprotective depending on when and where they form $[8,20]$. Irrespectively of the actual role of inclusions, it is clear that multiple factors modulate the effect of expanded polyglutamine in cells [23,24].

Although most studies of inclusions refer exclusively to NIIs, it is clear that NIIs are not the only aggregates that form in HD. We have previously described different morphologies of 
aggregates in a PC12 cell line [25] and a recent study shows that in vitro mutant huntingtin fragments can form two morphologically and conformationally distinct inclusion types that form differentially depending upon phosphorylation states of the protein [26]. It has not yet been shown if these different forms are present in vivo or in HD brains, but it seems increasingly likely that this will be the case. Aggregates of different morphologies have been shown in HD post mortem brains [4,10,27,28] and we have previously described a novel form of extranuclear aggregates that exists in the brains of R6/2 mice with very long CAG repeats [9]. In contrast to classic ENNIs, which are similar in morphology to NIIs (being electron-lucent, variable in both size and shape, and without definite structure) the novel neuropil ENNIs (nENNIs) are large, abundant, electron-dense and have a characteristic shape in mouse brain. In the present study, we characterized these inclusions and the surrounding brain at an electron magnetic (EM) level. We mapped the onset of appearance of nENNIs within the cortex, striatum and hippocampus of preand post- symptomatic R6/2 mice with two different CAG repeat lengths $(250$ and $>550)$. We then quantified neurodegeneration in these regions. We show for the first time that while the size of the CAG repeat expansion dictates the morphological form of the inclusions, the entry of neurons into neurodegenerative pathways occurs at around the same time (by 20 weeks of age) in mice with markedly different repeat lengths.

\section{Materials and methods}

\section{Animals}

We used lines of R6/2 mice that were derived from founder mice carrying the first exon of the human HTT gene with a pathologically expanded repeat that was originally around 140-150 CAG [29]. We have generated an allelic series of mice with different CAG repeat lengths, by exploiting the inherent instability of the CAG repeat [9]. Here we used a total of 64 male R6/2 
mice carrying a repeat of either $250 \pm 1$ CAG repeats $(n=24)$ or $550 \pm 3, n=40)$ CAGs. These lines of mice differ markedly in their clinical progression (for detailed description and relevant references, see [9]). Briefly, all mice from both lines are born and develop normally. Mice carrying a CAG repeat of 250 begin to show overt signs of disease at around 10-12 weeks of age, by which time their body weight has plateaued. After 14-16 weeks of age, they begin to lose weight, and concomitantly their symptoms worsen. Mice with a CAG repeat of 250 typically die at around 20-24 weeks. At end stage, they show marked muscle atrophy, hypoactivity, ptosis, lordokyphosis and ataxia. Mice with $550 \mathrm{CAG}$ repeats are indistinguishable from normal mice until around 30 weeks of age, when their growth stops. From around 40 weeks on, they begin to lose weight. They do not, however, show any overt signs of disease for at least a year. Their survival is similar to that of WT mice ( $>400 \mathrm{~d})$.

For histology, we used mice at 4 different ages between 8, 20, 22 for Q250 and Q550 mice and 8,20,52 and 104 weeks for Q550 mice respectively $(\mathrm{n}=4$ for each age and CAG repeat). All sections were stained with ubiquitin or MW8 antibodies.

For ultrastructural characterisation we used $250 \mathrm{CAG}$ repeat mice at 18 weeks of age or 400-550 CAG repeat mice aged 60 and 104 weeks ( $\mathrm{n}=4$ for each age and CAG repeat).

To map the distribution of inclusions, we used mice with 250 CAG repeats aged 12 and 25 weeks, and mice with 550 CAG repeats aged $12,25,55$ and 80 weeks $(n=4)$.

For quantification of neurodegeneration and volume measurements, we used mice with 250 CAG repeats aged 12 weeks, 20 weeks and endstage ( 22 weeks; $n=4$ for each age), and 550 CAG repeats at 12, 22, 52 and 104 weeks ( $\mathrm{n}=4$ for each age). 
Genotyping was performed by PCR from tail snips taken at 3 weeks of age and CAG repeat lengths were measured by Laragen (USA) as described previously [9]. After genotyping, mice were sorted by genotype and sex into experimental cages. Lighting was controlled on a $12 \mathrm{~h}$ light: $12 \mathrm{~h}$ dark. The housing facility temperature was maintained at $21-23{ }^{\circ} \mathrm{C}$ and the relative humidity was controlled $(55 \pm 10 \%)$. Mice had ad libitum access to water (via lowered waterspouts) and standard dry laboratory food. In addition, mice were given a supplementary feed each morning of a mash prepared by soaking $100 \mathrm{~g}$ dry food in $230 \mathrm{ml}$ of tap water until the pellets were soft and fully expanded. All experiments were conducted in accordance with the United Kingdom 1986 Animals (Scientific Procedures) Act.

\section{Electron microscopy}

Animals were fixed by perfusion with $4 \%$ glutaraldehyde containing $2 \mathrm{mM} \mathrm{CaCl}_{2}$ in $0.1 \mathrm{M}$ PIPES buffer at $\mathrm{pH}$ 7.4. The animals were killed by a lethal overdose of pentobarbital and then intracardially perfused with buffered saline containing 10 mmol/1 PIPES buffer, $\mathrm{pH}$ 7.4, 139 $\mathrm{mmol} / 1$ sodium chloride, $2.7 \mathrm{mmol} / 1$ potassium chloride, $2 \mathrm{mmol} / 1$ calcium chloride, $5 \mathrm{mmol} / \mathrm{l}$ sodium nitrite, $19.4 \mathrm{mmol} / \mathrm{l}$ glucose and $2.5 \%$ polyvinylpyrrolidone (FW 40000) at room temperature. This was followed by perfusion with $300 \mathrm{ml}$ of cold $\left(4^{\circ} \mathrm{C}\right)$ fixative for 15 minutes containing $4 \%$ glutaraldehyde, $0.5 \%$ formaldehyde, $2 \mathrm{mmol} / 1$ calcium chloride and $2.5 \%$ polyvinylpyrrolidone (FW 40000) in $100 \mathrm{mmol} / 1$ PIPES buffer, $\mathrm{pH}$ 6.0. The brains were then removed and cut into $0.5 \mathrm{~mm}$ slices and trimmed to a $1 \times 1 \mathrm{~mm}$ area containing the regions of interest. These samples were then post-fixed over night at $4^{\circ} \mathrm{C}$. They were washed twice in $0.1 \mathrm{M}$ PIPES buffer $(\mathrm{pH} 6.0)$. Then post-fixed in $2 \%$ osmium tetroxide containing $2 \%$ osmium ferricyanide containing $2 \mathrm{mmol} / \mathrm{l}$ calcium chloride for 2 hours at $4^{\circ} \mathrm{C}$, rinsed 3 times in deionised distilled water and bulk stained in $2 \%$ uranyl acetate for $1 \mathrm{~h}$. Subsequently rinsed in deionised 
distilled water and dehydrated in an ascending series of ethanol solutions to $100 \%$ ethanol, rinsed twice in acetonitrile and embedded in Quetol epoxy resin. Fifty nm sections were cut on a Leica Ultracut UCT, stained with saturated uranyl acetate in 50\% ethanol and lead citrate and viewed in a FEI Philips CM100 operated at 80kV.

\section{Histology}

\section{Immunohistochemistry}

Mice were killed by asphyxiation with rising levels of $\mathrm{CO}_{2}$. The brains were removed and immediately frozen in dry ice. Coronal cryosections $(30 \mu \mathrm{m})$ were cut serially through the whole brain of each mouse onto 10 gelatinised slides and processed for histochemical and immunohistochemical staining. One slide from each mouse was stained with haematoxylin and eosin (H \& E) or cresyl violet to aid identification of anatomical regions. Primary antibodies used were a rabbit anti-ubiquitin antibody (1:2000 dilution, DAKO), and an anti-Htt mouse monoclonal antibody (MW8) raised against the N-terminal portion of Htt with an expanded repeat (1:2000 dilution, raised by Dr. Paul Patterson and obtained from the Developmental Studies Hybridoma Bank, University of Iowa, Iowa City, USA). A horseradish peroxidaseconjugated second antibody (1:2000 dilution, DAKO, USA) was used, and immunoreactive elements were visualised using diaminobenzidine.

\section{Nissl staining}

Mice were perfused transcardially with $4 \%$ paraformaldehyde and immersion fixed for at least 1 week in $4 \%$ paraformaldehyde in $0.1 \mathrm{M}$ phosphate-buffered saline (PBS) and subsequently cryoprotected in a solution of $30 \%$ sucrose in PBS. Sections $(50 \mu \mathrm{m})$ were cut serially through the whole brain of each mouse, making coronal sections. The sections were then mounted onto 
gelatinised slides in order to be processed for Nissl staining.

Slides were stained with Cresyl violet (Sigma Chemical Company, Dorset, UK) to enable brain regions to be identified. Slides were defatted in Histoclear (Cellpath, Powys, Mid Wales, UK) for $3 \mathrm{~min}$, followed by dehydration for 2 min each in absolute ethanol and 95\% ethanol, and $1 \mathrm{~min}$ in $70 \%$ ethanol. The sections were then washed with clean tap water for 30-60 s. After soaking in $1 \%$ Cresyl violet for 15 min, slides were again washed with tap water for 30-60 s until the water ran clear. They were then differentiated for $10 \mathrm{~s}$ in $1 \%$ acetic acid/alcohol and washed in distilled water. After $1 \mathrm{~min}$ in $70 \%$ ethanol, slides were placed for 2 min in each of $95 \%$ then absolute ethanol twice. Samples were placed in three successive pots of Histoclear for 1, 3 and 3 min, respectively, and coverslipped with DPX mounting medium (BDH, Lutterworth, Leicestershire, UK). After mounting the slides were dried in an oven at $37^{\circ} \mathrm{C}$ for at least 24 hours.

\section{Measurements of brain region volumes}

Unbiased Cavalieri estimates of the volume [30] caudate putamen $(\mathrm{CPu})$, primary somatosensory cortex (S1BF) and primary motor cortex (M1) were made on Nissl or immunohistochemically stained sections, measuring every sixth section, using a Nikon Eclipse 80i microscope and StereoInvestigator software (MBF Bioscience, Williston, VT, USA), with the investigator blind to genotype. An appropriately spaced sampling grid (200 $\mu \mathrm{m}$ for $\mathrm{CPu}$ and $\mathrm{S} 1 \mathrm{BF}, 150 \mu \mathrm{m}$ for M1) was superimposed over the sections and the number of points covering the relevant areas counted using an $\mathrm{x} 2$ objective. Regional volumes expressed in $\mu \mathrm{m}^{3}$ were collected for each animal and the mean volume of each region obtained for R6/2 and WT mice. The delineation of each region was consistently performed by referring to the Paxinos and Franklin Mouse Brain Atlas.

\section{Counts of neuronal number}


To examine neuronal survival within the areas of interest we used StereoInvestigator software to obtain unbiased optical fractionator estimates of neuronal number in Nissl stained sections ${ }^{1}$. These estimates were obtained for $\mathrm{CPu}$, and cortical layers IV, V and VI in S1BF and M1. These measures were performed with a random starting section, followed by every sixth Nissl stained section thereafter. For $\mathrm{CPu}$, the counting frame size was $30 \mu \mathrm{m} \times 30 \mu \mathrm{m}$ and the grid size used was $280 \mu \mathrm{m} \times 350 \mu \mathrm{m}$. For all layers in S1BF, the counting frame size was $25 \mu \mathrm{m} \times$ $25 \mu \mathrm{m}$ and the grid size used was $200 \mu \mathrm{m} \times 180 \mu \mathrm{m}$. For all layers in M1, the counting frame size was $30 \mu \mathrm{m} \times 30 \mu \mathrm{m}$ and the grid size used was $200 \mu \mathrm{m} \times 80 \mu \mathrm{m}$.

\section{Statistical Analysis}

An ANOVA was used to analyse all volume and quantification data. In both cases, post-hoc Bonferroni tests were performed and $P<0.05$ was considered as statistically significant. For all optical fractionator estimates, the mean coefficient of error (CE) of individual estimates was calculated according to the method of Gundersen and Jensen [30] and was less than 0.05 in all these analyses.

\section{Results}

\section{Ultrastructure of novel ENNIs}

In contrast to classic ENNIs, which are ultrastructurally similar to NIIs (electronluscent, and

\footnotetext{
${ }^{1}$ Stereology is a systematic sampling method that consists of sampling a region at a random starting position, utilizing a defined periodicity in which all portions in the region have an equal probability of being sampled [31]. A random sampling start between sections of interest within the area is used reduce the variance of the end result, without exhaustive counting [32]. The optical fractionator method is where an optical disector in a strictly random and systematic sampling scheme covers a known fraction of the region being analysed [33]. As such, the exact thickness or area of the section is not needed for calculations. This provides an unbiased count independent on shrinkage, expansion of the tissue and dimensional changes in the tissue [34,35].
} 
without a definite structure; Fig. 1A), nENNIs are large, abundant and electron dense and therefore very easy to identify without immunogold labelling (Fig. 1B-D). Our ultrastructural data show that nENNIs are typically round or oval and located in both non-myelinated (Fig. 1B) and myelinated (Fig. 1D) processes. They are unbounded by a membrane and frequently fill the axon or neurite. When they do so, they push organelles such as mitochondria to the periphery of the process (arrows, Fig. 1C and D).

Interestingly, novel ENNIs appear to 'mature' with age (Fig. 2). Both their density and size increased with age, and some of them display a core that is more electrondense than the surrounding inclusion material (Fig. 2). Some nENNIs in older animals appear to be multilayered (Fig. 2B, C and D), suggesting that nENNIs with cores are more 'mature' than those without.

\section{Progressive appearance of $n E N N I$ s is age- and CAG repeat length dependent}

NNIs and nENNIs are detected with the same antibodies, thus for definitive characterisation, the nucleus needs to be visualised to allow the distinction between both types. Because ENNIs are present in axons and neurites, appear in different regions at different times, and vary markedly in size, it is difficult to quantify them in a meaningful way. To illustrate their progressive appearance, we have therefore presented a series of micrographs at low and high magnification showing typical morphological appearance of nENNIs in the lacunosum molecular, a region of the hippocampus that was chosen because it has few cell bodies and is composed mainly of neuropil where these inclusions are formed (Fig. 3). Note that there are both NNIs and ENNIs in these photomicrographs.

We mapped the distribution of nENNIs stained with ubiquitin or MW8 in the R6/2 mouse brain manually, by excluding inclusions that were present in nuclei. We have illustrated them as a cartoon heat map at 4 different ages (Fig. 4). The distribution of nENNIs is markedly different 
from that of NIIs that has been described previously $[8,36]$. nENNI distribution also varies depending upon the age of the mice and the CAG repeat length. In Q250 mice aged 12 weeks, we found a few scattered nENNIs in the cortex, $\mathrm{CPu}$, thalamus and hippocampus, although there were numerous NIIs, as previously described [8]. By 20 weeks of age the density of nENNIs had increased and by end-stage ( 22 weeks of age) nENNIs were more numerous and larger than they had been at younger ages (see Fig. 3C and $\mathrm{C}^{\prime}$ for detail from Hf). In Q550 mouse brains, no nENNIs were visible at 12 weeks of age. However, by 20 weeks of age numerous small nENNIs were present in the cortex, $\mathrm{CPu}$, and hippocampus. At 104 weeks of age (end-stage), large sized nENNIs were abundantly present in the cortex, $\mathrm{CPu}$, and hippocampus (Fig. 3F and F'). Interestingly, MW8 staining shows a decreased intensity at the later stage in Q550 repeat mouse brains. We suggest that this is due to the fact that ubiquitination takes place after aggregate formation [37] and that in mature ubiqutinated aggregates the epitope for MW8 binding is masked.

\section{Neurodegenerative profiles are present in brains of super-long CAG repeat mice from 20} weeks of age

Despite the fact that the aggregate load was low, using electron microscopy we revealed pronounced morphological abnormalities in the brain tissue of R6/2 mice with $550 \mathrm{CAG}$ repeats at 20 weeks of age (Fig. 5). This is interesting, because at this age, $550 \mathrm{CAG}$ repeat mice have few inclusions, and are many months from the age at which they would be expected to show overt symptoms. We found nENNIs that filled neural processes in all brain regions, where the large aggregates have pushed inner organelles, such as mitochondria, to the periphery of the processes (Fig. 5A). In addition numerous damaged mitochondria were present (Fig. 5B). Furthermore, vacuoles were common (Fig. 5C-E), particularly in processes. Abnormalities in 
axonal myelin sheaths were readily observed (Fig. 5C). Importantly, degenerating neurons were found in all brain regions studied. Degenerating neurons showing characteristics of multiple different types of cell death such as dark cell death (Fig. 5D), apoptosis and necrosis (Fig. 5E and F respectively) were seen in the cortex (Fig. 5) as well as in the $\mathrm{CPu}$ and hippocampus (data not shown).

\section{Different volume loss profiles in $R 6 / 2$ mice with different $C A G$ repeat length}

Because we could observe neurodegeneration in the brain tissue of R6/2 mice with expanded CAG repeats and regional brain atrophy correlated directly with cell loss, we decided to measure the volume of brain regions of interest using the Cavalieri estimator. We measured the volume of $\mathrm{CPu}, \mathrm{S} 1 \mathrm{BF}$ and $\mathrm{M} 1$ in R6/2 Q250, R6/2 Q550 mice and age-matched controls. As expected from previous analysis [38], we found that significant volume loss occurred in all the regions in R6/2 Q250 mice (Fig. 6A, C and E). The volume loss occurred by 20 weeks of age in the cortex and by 22 weeks of age in the $\mathrm{CPu}$. This is late/end stage in those mice that typically die at around 25 weeks of age.

In Q550 mice, the volume loss was also apparent early and was progressive. Atrophy was apparent from a much younger age in the $\mathrm{CPu}$ of Q550 mice than it was in Q250 mice despite the fact that the latter mice had a very severe phenotype. Atrophy was significant by 12 weeks of age in the $\mathrm{CPu}(\mathrm{p}<0.05$, Fig. 6B) and 22 weeks of age in $\mathrm{S} 1 \mathrm{BF}(\mathrm{p}<0.05$, Fig. 6D). In M1, there was a

trend to decreased volume at 22 weeks of age, but it did not reach significance $(p=0.056)$. However, volume loss in M1 was statistically significant by 52 weeks of age $(p<0.05)$ (Fig. 6F).

\section{Volume loss is mirrored by neuronal loss}


The presence of neurodegenerative profiles as well as atrophy suggested that the neurodegeneration occurring at end stage in the brains of R6/2 Q550 mice is extensive. Thus, we decided to quantify neuronal loss directly using unbiased stereology. We compared the extent of neuronal loss in R6/2 Q250 and R6/2 Q550 with their age-matched controls. In R6/2 Q550 mice, neuron loss was apparent from a much younger age than it was in the more severely affected Q250 mice. In the $\mathrm{CPu}$ of R6/2 Q250 mice, we found that significant neuron loss occurred by 22 weeks of age (Fig. 7A), and although volume loss was already apparent at 12 weeks of age, neuronal loss was consistent with volume loss. In R6/2 Q550 mice, neuron loss was also significant at 22 weeks of age (Fig. 7B).

In S1BF (Fig. 8), neuron loss was observed in lamina V in both R6/2 Q250 and Q550 mice, but not from any other layer. Significant neuron loss occurred by 22 weeks of age (Fig. 8C), and mirrored volume loss. Interestingly, given that the mice were asymptomatic, in R6/2 Q550 mice, neuron loss was also significant at 22 weeks of age (Fig. 8D). No neuron loss was seen in lamina IV or VI (Lam IV, Lam VI, Fig. 8A, B, E and F) in either R6/2 Q250 or R6/2 Q550 mice.

In motor cortex (M1; Fig. 9), in the R6/2 Q250 mice neuronal loss was seen in lamina IV at 20 and 22 weeks of age (Fig. 9A). By contrast, in R6/2 Q550 mice, neuronal loss was not seen until 104 weeks of age, at which age it was present in all laminae (Fig. 9B, D and F).

\section{DISCUSSION}

In this study we characterised the distribution and morphology of nENNIs in the R6/2 mouse brain. We show that nENNIs are present in both Q250 and Q550 R6/2 mice at 20-22 weeks of age, but they are considerably more numerous in Q550 R6/2 mice. Despite the marked difference in aggregate load, both Q250 and Q550 mice show similar, albeit mild, brain volume and neuron loss in the striatum and the cortex by 20-22 weeks of age. This was interesting, given at that age 
Q250 mice were severely symptomatic (end stage), whereas Q550 mice had as yet no overt behavioural or physiological abnormal phenotype.

\section{Characterisation of a novel form of neuropil ENNIs}

The main form of inclusion described so far in HD mice and patients, has been the NII $[4,10,39]$. These were first discovered in R6/2 mice and their presence was consequently confirmed in HD patients $[4,10]$ and other HD mouse models [4,16,40-43]. There are, however, major differences between distribution of NIIs mouse models and human post mortem brains, with NIIs being markedly more abundant in mice. Despite this difference, NIIs inclusions have remained the main focus of attention when brain aggregates have been considered. As well as NIIs, ENNIs have also been reported in brains of HD patients $[4,5,17,28,44,45]$. However, the extranuclear aggregates described thus far in R6/2 mice by us and other groups are structurally similar to NIIs $[8,46]$.

In contrast to the report by Dragatsis et al. [47] that cytoplasmic inclusions were found in the cell body, the nENNIs we report are found predominantly in processes in the neuroplil. Although we have searched persistently, we have never seen an ENNI with either classical or novel morphology in the cytoplasm of medium spiny neurons in our EM sections. This suggests that the ENNIs found by Dragatsis and colleagues (in a line of mice that arose independently) are a different type of aggregates to the nENNIs that we report here. Furthermore, nENNIs are ustrastructurally different from the ENNIs described previously. The nENNIs we observe are large, ovoid and electron dense, and both increase in size and change morphologically ('mature') with age. The age-related changes in morphology of these inclusions is interesting given a recent studies by Caron et al. [48] in which they showed that mutant Htt can aggregated differently depending on its phosphorylation state. These authors suggested that since the protein exists in different configuration that this might change packing density of the protein, so that the fibrilar 
protein is more densely packed than the globular protein. It would be interesting to see if the phosphorylation state of proteins that make up the two kinds of aggregates we see in mouse brain in vivo is differentially phosphorylated, or if the protein composition changes as an aggregate 'matures'. It is not clear if the nENNIs described in our study are the same as those described in HD patients. Although nENNIs closely resemble the neuropil inclusions present in dystrophic neurites in human tissue described by DiFiglia et al. [4], no comprehensive EM study of inclusion morphology has been conducted on human brain aggregates.

Despite a considerably higher burden of nENNIs and unequivocal neurodegeneration seen at a presymptomatic age, mice with longer CAG repeats have a considerably longer life span and delayed onset of symptoms than Q250 mice $[9,47]$. In fact some mice with very long repeats reach a normal life span despite the presence of high total aggregate load and clinical signs [9]. This suggests that nENNIs are not as toxic as NIIs. It is possible that the formation of nENNIs reduces the activation of toxicity by-products or pathways by mutant Htt. This mechanism was suggested by Dragatsis et al. [47] who found an expanded lifespan in mice with $>350$ CAG repeats and suggested that nuclear accumulation of mutant protein in R6/2 mice may contribute to the more aggressive phenotype in R6/2 mice with shorter repeats. Alternatively, a recent in vitro study also revealed that DNA with super-long repeats contains unusual structures, which could contribute to decreased transcriptional regulation of the Htt gene [49]. It is also possible that the expanded polyQ reduces the translocation of the Htt fragments into the nucleus and that this contributes to the delay in the phenotype of the mutant mice. Such a mechanism has been observed in the caspase-6 resistant YAC mice [50] as well as in the short-stop YAC mice [51] where both lines exhibit a heavy aggregate load, but lack a behavioural phenotype. Finally, it is possible that nENNIs are acting as modifiers of poly-Q induced toxicity. In a recent study on 
R6/1 mice [52], the authors suggested that mutant Htt could induce the aggregation of other misfolding-prone proteins, such as $\alpha$-synuclein, via a cross-seeding mechanism leading to the disruption of the ubiquitin-proteasome system. This seems very plausible to us. Indeed, aggregates containing $\alpha$-synuclein have been reported in HD patients [53]. Interestingly, it appears that $\alpha$-synuclein acts as a modifier of polyQ-induced toxicity in mice, and knocking-out $\alpha$-synuclein resulted in the attenuation of the HD motor phenotype, weight loss and load of inclusion [52]. Finally, a recent finding shows that Htt can alter tau phosphorylation and subcellular distribution [54]. Such alterations in protein conformation due to the HD mutation might contribute to the time course of disease progression.

\section{Neurodegeneration in R6/2 mice}

R6/2 mice with low CAG repeats exhibit only moderate neuron degeneration in the late stage $[29,39,40,42,43,55-59]$. The reason for the disparity between brain pathology and phenotype are likely to be complex. For example, there is considerable peripheral pathology in these mice [6065], so the rapid deterioration in phenotype is unlikely to be due solely to brain dysfunction.

Neuron loss in Q550 mice could be triggered by trafficking impairment due to the physical presence of nENNIs in the processes. Indeed, in many processes we found inclusions pushing organelles, particularly mitochondria, to the periphery. To our knowledge, this has not been observed previously, in either mice or HD patients. It might be expected, however, that dislocated organelles may not function normally. Many studies have shown that trafficking defects can impair neurotransmission due to disrupted delivery of proteins at the synapse [66-68] and lead to neuron loss. In this study, as well as displaced mitochondria, we have also observed abnormal mitochondria. This is consistent with the mitochondrial abnormalities seen in HD. Structural mitochondrial defects have been linked to damaged mtDNA [69,70] which is an early biomarker 
for HD-associated neurodegeneration and supports the hypothesis that mtDNA lesions may contribute to the pathogenesis observed in HD [71]. Recently, mitochondrial abnormalities have been found in post mortem brains and peripheral tissues of HD patients [72-74] as well as in in vitro models of HD [74,75].

It is striking that brains of R6/2 mice with super long CAG repeats exhibit profound neuron loss in the striatum and in some regions in the cortex, despite their normal lifespan. Thus neuronal loss per se does not cause the symptoms in the mouse. In HD patients also, neuronal degeneration occurs first in the striatum [6], then in other areas of the brain [28,76,77]. It is notable that significant loss of basal ganglia volume [78-83] and neuron loss [84] have been reported in asymptomatic HD patients. The appearance of inclusions in HD patients also precedes the onset of symptoms and neurodegeneration $[4,5,16,85]$.

\section{CONCLUSION}

Our study confirms a late-onset slowly progressing phenotype in mice with $>550 \mathrm{CAG}$ repeats, despite the presence of neurodegeneration from as early as 22 weeks of age. It remains a challenge to establish a direct link between repeat size in mice, the presence of aggregates and neuronal loss. R6/2 mice with $>550$ CAG repeats display a pathology that correlates with the presence of nENNIs, but not NIIs. Our study highlights the need to understand the relative contribution of different kinds of inclusions to different aspects of pathology in HD and also to determine the mechanisms underlying neurodegeneration. R6/2 mice with long CAG repeats that show early neurodegeneration in the absence of clinical signs will be useful tools for such studies.

\section{ACKNOWLEDGEMENTS}


We would like to thank W. Leavens and Z. Zheng for excellent technical support.

This work was funded by CHDI Inc. (USA)

\section{REFERENCES}

1. Huntington's Disease Collaborative Research Group. A novel gene containing a trinucleotide repeat that is expanded and unstable on Huntington's disease chromosomes. Cell 1993; 72 (6): 971-83.

2. Roos RAC. Huntington's disease: A clinical review. Orphanet J Rare Dis. 2010; 5: 40.

3. Bates G, Tabrizi S, Jones L. Huntington's disease, 4th ed. Oxford: Oxford University Press; 2014.

4. DiFiglia M, Sapp E, Chase KO, Davies SW, Bates GP, Vonsattel JP, Aronin N. Aggregation of huntingtin in neuronal intranuclear inclusions and dystrophic neurites in brain. Science 1997; 277 (5334): 1990-93

5. Sapp E, Penney J, Young A, Aronin N, Vonsattel Jp, DiFiglia M. Axonal transport of N-terminal huntingtin suggests early pathology of corticostriatal projections in Huntington disease. J Neuropathol Exp Neurol. 1999; 58 (4):165-73.

6. Vonsattel JP, Myers RH, Stevens TJ, Ferrante RJ, Bird ED, Richardson EP Jr. Neuropathological classification of Huntington's disease. J Neuropathol Exp Neurol. 1985; 44 (6):559-77.

7. Vonsattel JP, DiFiglia M. Huntington disease. J Neuropathol Exp Neurol. 1998; 57 (5):369-384.

8. Morton AJ, Lagan MA, Skepper JN, Dunnett SB. Progressive formation of inclusions in the striatum and hippocampus of mice transgenic for the human Huntington's disease mutation. J Neurocytol 2000; 29 (9): 679-02.

9. Morton AJ, Glynn D, Leavens W, Zheng Z, Faull RL, Skepper JN, Wight JM. Paradoxical delay in the onset of disease caused by super-long CAG repeat expansions in R6/2 mice. Neurobiol Dis 2009; 33 (3): 331-41.

10. Maat-Schieman M, Roos R, Losekoot M, Dorsman J, Welling-Graafland C, Hegeman-Kleinn I, Broeyer F, Breuning M, van Duinen S. Neuronal intranuclear and neuropil inclusions for pathological assessment of Huntington's disease. Brain Pathol 2007; 17 (1): 31-37.

11. Ordway JM, Tallaksen-Greene S, Gutekunst CA, Bernstein EM, Cearley JA, Wiener HW, Dure LS 4th, Lindsey R, Hersch SM, Jope RS, Albin RL, Detloff PJ. Ectopically expressed CAG repeats cause intranuclear inclusions and a progressive late onset neurological phenotype in the mouse. Cell 1997; 91 (6): 753-63.

12. Cooper JK, Schilling G, Peters MF, Herring WJ, Sharp AH, Kaminsky Z, Masone J, Khan FA, Delanoy M, Borchelt DR, Dawson VL, Dawson TM, Ross CA. Truncated N-terminal fragments of huntingtin with expanded glutamine repeats form nuclear and cytoplasmic aggregates in cell culture. Hum Mol Genet 1998; 7 (5): 783-90.

13. Rubinsztein DC, Wyttenbach A, Rankin J. Intracellular inclusions, pathological markers in diseases caused by expanded polyglutamine tracts? J Med Genet 1999; 36 (4): 265-70.

14. Rankin J, Wyttenbach A, RubinszteinDC. Intracellular green fluorescent protein-polyalanine aggregates are associated with cell death. Biochem J 2000; 15 (Pt1): 15-19. 
15. Saudou F, Finkbeiner S, Devys D, Greenberg ME. Huntingtin acts in the nucleus to induce apoptosis but death does not correlate with the formation of intranuclear inclusions. Cell 1998; 95 (1): 55-66.

16. Gutekunst CA, Li SH, Yi H, Mulroy JS, Kuemmerle S, Jones R, Rye D, Ferrante RJ, Hersch SM, Li XJ. Nuclear and neuropil aggregates in Huntington's disease: relationship to neuropathology. J Neurosci 1999; 19 (7): 2522-34.

17. Kuemmerle S, Gutekunst CA, Klein AM, Li XJ, Li SH, Beal MF, Hersch SM, Ferrante RJ. Huntington aggregates may not predict neuronal death in Huntington's disease. Ann Neurol 1999; 46 (6): 842-49.

18. Hansson O, Guatteo E, Mercuri NB, Bernardi G, Li XJ, Castilho RF, Brundin P. Resistance to NMDA toxicity correlates with appearance of nuclear inclusions, behavioural deficits and changes in calcium homeostasis in mice transgenic for exon 1 of the huntington gene. Eur J Neurosci 2001; 14 (9): 1492-04.

19. Arrasate M, Mitra S, Schweitzer ES, Segal MR, Finkbeiner S. Inclusion body formation reduces levels of mutant huntingtin and the risk of neuronal death. Nature. 2004; 431 (7010): 805-10.

20. Gong B, Lim MC, Wanderer J, Wyttenbach A, Morton AJ. Time-lapse analysis of aggregate formation in an inducible PC12 cell model of Huntington's disease reveals time-dependent aggregate formation that transiently delays cell death. Brain Res Bull 2008; 75 (1): 146-57.

21. Miller J, Arrasate M, Shaby BA, Mitra S, Masliah E, Finkbeiner S. Quantitative relationships between huntingtin levels, polyglutamine length, inclusion body formation, and neuronal death provide novel insight into huntington's disease molecular pathogenesis. J Neurosci. 2010; 30 (31):10541-50.

22. Duennwald ML. Polyglutamine misfolding in yeast: toxic and protective aggregation. Prion. 2011; 5 (4):285-90.

23. Young D, Mayer F, Vidotto N, Schweizer T, Berth R, Abramowski D, Shimshek DR, Herman van der Putten P, Schmid P. Mutant huntingtin gene-dose impacts on aggregate deposition, DARPP32 expression and neuroinflammation in HdhQ150 mice. PLoS One. 2013; 8 (9): e75108.

24. Bersuker K, Hipp MS, Calamini B, Morimoto RI, Kopito RR. Heat shock response activation exacerbates inclusion body formation in a cellular model of Huntington disease. J Biol Chem. 2013; 288 (33): 23633-23638.

25. Wanderer J, Morton AJ. Differential morphology and composition of inclusions in the R6/2 mouse and PC12 cell models of Huntington's disease. Histochem. Cell Biol. 2007; 127 (5):47384.

26. Caron NS, Hung CL, Atwal RS, Truant R. Live cell imaging and biophotonic methods reveal two types of mutant huntingtin inclusions. Hum Mol Genet. 2014; 23(9):2324-2338.

27. Becher MW, Kotzuk JA, Sharp AH, Davies SW, Bates GP, Price DL, Ross CA. Intranuclear neuronal inclusions in Huntington's disease and dentatorubral and pallido- luysian atrophy: correlation between the density of inclusions and IT15 CAG triplet repeat length. Neurobiol Dis. 1998; 4 (6): 387- 397.

28. Rüb U, Hentschel M, Stratmann K, Brunt E, Heinsen H, Seidel K, Bouzrou M, Auburger G, Paulson H, Vonsattel JP, Lange H, Korf HW, den Dunnen W. Huntington's disease (HD): degeneration of select nuclei, widespread occurrence of neuronal nuclear and axonal inclusions in the brainstem. Brain Pathol 2014. 24:247-260

29. Mangiarini L, Sathasivam K, Seller M, Cozens B, Harper A, Hetherington C, Lawton M, Trottier Y, Lehrach H, Davies SW, Bates GP. Exon 1 of the HD gene with an expanded CAG repeat is sufficient to cause a progressive neurological phenotype in transgenic mice. Cell 1996; 87 (3): 493-06. 
30. Gundersen HJ, Jensen EB. The efficiency of systematic sampling in stereology and its prediction. J Microsc. 1987; 147 (Pt3):229-63.

31. Gundersen HJ. The efficiency of systematic sampling in stereology--reconsidered. J Microsc. 1999 Mar;193(Pt 3):199-211.

32. Boyce RW, Dorph-Petersen KA, Lyck L, Gundersen HJ. Design-based stereology: introduction to basic concepts and practical approaches for estimation of cell number. Toxicol Pathol. 2010 Dec; 38(7):1011-25.

33. Cruz-Orive LM. Stereology of single objects. 1997 J Microsc. 1997 186(2):93-107.

34. Braendgaard H, Gundersen HJ. The impact of recent stereological advances on quantitative studies of the nervous system. 1986 J Neurosci Methods. 1986 Oct;18(1-2):39-78.

35. West MJ, Slomianka L, Gundersen HJ. Unbiased stereological estimation of the total number of neurons in thesubdivisions of the rat hippocampus using the optical fractionator. Anat Rec. 1991. 231(4):482-97.

36. Meade CA, Deng YP, Fusco FR, Del Mar N, Hersch S, Goldowitz D, Reiner A.. Cellular localization and development of neuronal intranuclear inclusions in striatal and cortical neurons in R6/2 transgenic mice. J Comp Neurol. 2002;449(3):241-69.

37. Gong B, Kielar C, Morton AJ. Temporal separation of aggregation and ubiquitination during early inclusion formation in transgenic mice carrying the Huntington's disease mutation. PLoS One. 2012; 7 (7):e41450.

38. Sawiak SJ, Wood NI, Williams GB, Morton AJ, Carpenter TA. Use of magnetic resonance imaging for anatomical phenotyping of the R6/2 mouse model of Huntington's disease. Neurobiol Dis. 200933 (1):12-9.

39. Davies SW, Turmaine M, Cozens BA, DiFiglia M, Sharp AH, Ross CA, Scherzinger E, Wanker EE, Mangiarini L, Bates GP. Formation of neuronal intranuclear inclusions underlies the neurological dysfunction in mice transgenic for the HD mutation. Cell 1997; 90 (3): 537-548.

40. Wheeler VC, Auerbach W, White JK, Srinidhi J, Auerbach A, Ryan A, Duyao MP, Vrbanac V, Weaver M, Gusella JF, Joyner AL, MacDonald ME. Length-dependent gametic CAG repeat instability in the Huntington's disease knock-in mouse. Hum Mol Genet. 1999; 8 (1): 115-22.

41. Wheeler VC, Lebel LA, Vrbanac V, Teed A, te Riele H, MacDonald ME. Mismatch repair gene Msh2 modifies the timing of early disease in $\operatorname{Hdh}(\mathrm{Q} 111)$ striatum. Hum. Mol. Genet. 2003; 12 (3): 273-281.

42. Menalled LB, Sison JD, Dragatsis I, Zeitlin S, Chesselet MF. Time course of early motor and neuropathological anomalies in a knock-in mouse model of Huntington's disease with $140 \mathrm{CAG}$ repeats. J Comp Neurol. 2003; 465 (1): 11-26.

43. van Raamsdonk JM, Murphy Z, Slow EJ, Leavitt BR, Hayden MR. Selective degeneration and nuclear localization of mutant huntingtin in the YAC128 mouse model of Huntington disease. Hum Mol Genet. 2005; 14 (24): 3823-35.

44. Maat-Schieman ML, Dorsman JC, Smoor MA, Siesling S, Van Duinen SG, Verschuuren JJ, den Dunnen JT, Van Ommen GJ, Roos RA. Distribution of inclusions in neuronal nuclei and dystrophic neurites in Huntington disease brain. J Neuropathol Exp Neurol. 1999; 58 (2):129-137.

45. Sieradzan KA, Mechan AO, Jones L, Wanker EE, Nukina N, Mann DM. Huntington's disease intranuclear inclusions contain truncated, ubiquitinated huntingtin protein. Exp Neurol. 1999; 156 (1):92-9.

46. Li H, Li SH, Cheng AL, Mangiarini L, Bates GP, Li XJ. Ultrastructural localization and progressive formation of neuropil aggregates in Huntington's disease transgenic mice. Hum Mol Genet. 1999; 8 (7):1227-36. 
47. Dragatsis I, Goldowitz D, Del Mar N, Deng YP, Meade CA, Liu L, Sun Z, Dietrich P, Yue J, and Reiner A. CAG repeat lengths $>$ or $=335$ attenuate the phenotype in the R6/2 Huntington's disease transgenic mouse. Neurobiol Dis. 2009; 33 (3):315-30.

48. NS Caron NS, Hung CL, Atwal RS, Truant R. Live cell imaging and biophotonic methods reveal two types of mutant huntingtin inclusions. Hum Mol Gen. 2014; 23:2324-2338.

49. Duzdevich D, Li J, Whang J, Takahashi H, Takeyasu K, Dryden DTF, Morton AJ, Edwardson JM. Unusual structures are present in DNA fragments containing super-long Huntingtin CAG repeats. PLoS One. 2011; 6 (2):e17119.

50. Graham RK, Deng Y, Slow EJ, Haigh B, Bissada N, Lu G, Pearson J, Shehadeh J, Bertram L, Murphy Z, Warby SC, Doty CN, Roy S, Wellington CL, Leavitt BR, Raymond LA, Nicholson DW, Hayden MR. Cleavage at the caspase-6 site is required for neuronal dysfunction and degeneration due to mutant huntingtin Cell. 2006; 125(6):1179-1191.

51. Slow EJ, Graham RK, Osmand AP, Devon RS, Lu G, Deng Y, Pearson J, Vaid K, Bissada N, Wetzel R, Leavitt BR, Hayden MR. Absence of behavioral abnormalities and neurodegeneration in vivo despite widespread neuronal huntingtin inclusions. Proc Natl Acad Sci U S A. 2005; 102(32):11402-11407.

52. Tomas-Zapico C, Díez-Zaera M, Ferrer I, Gómez-Ramos P, Morán MA, Miras-Portugal MT, Díaz-Hernández M, Lucas JJ. $\alpha$-Synuclein accumulates in huntingtin inclusions but forms independent filaments and its deficiency attenuates early phenotype in a mouse model of Huntington's disease. Hum Mol Genet. 2012; 21(3):495-510.

53. Charles V, Mezey E, Reddy PH, Dehejia A, Young TA, Polymeropoulos MH, Brownstein MJ, Tagle DA. Alpha-synuclein immunoreactivity of huntingtin polyglutamine aggregates in striatum and cortex of Huntington's disease patients and transgenic mouse models. Neurosci Lett. 2000; 289:29-32.

54. Blum D, Herrera F, Francelle L et al. Mutant huntingtin alters Tau phosphorylation and subcellular distribution. Hum Mol Genet. 2014; 24 (1): 76-85.

55. Yu ZX, Li SH, Evans J, Pillarisetti A, Li H, Li XJ. Mutant huntingtin causes context-dependent neurodegeneration in mice with Huntington's disease. J Neurosci. 2003; 23 (6): 2193-202.

56. Heng MY, Tallaksen-Greene JS, Detloff PJ, Albin RL. Longitudinal evaluation of the Hdh(CAG)150 knock-in murine model of Huntington's disease. J Neurosci. 2007; 27 (34): 898998.

57. Woodman B, Butler R, Landles C, Lupton MK, Tse J, Hockly E, Moffitt H, Sathasivam K, Bates GP. The Hdh(Q150/Q150) knock-in mouse model of HD and the R6/2 exon 1 model develop comparable and widespread molecular phenotypes. Brain Res Bull. 2007; 72 (2-3): 83-97.

58. Gray M, Shirasaki DI, Cepeda C, André VM, Wilburn B, Lu XH, Tao J, Yamazaki I, Li SH, Sun YE, Li XJ, Levine MS, Yang XW. Full-length human mutant huntingtin with a stable polyglutamine repeat can elicit progressive and selective neuropathogenesis in BACHD mice. $\mathrm{J}$ Neurosci. 2008; 28 (24): 6182-95.

59. Turmaine M, Raza A, Mahal A, Mangiarini L, Bates GP, Davies SW. Nonapoptotic neurodegeneration in a transgenic mouse model of Huntington's disease. Proc Natl Acad Sci U S A. 2000; 97 (14):8093-7.

60. Moffitt H, McPhail GD, Woodman B, Hobbs C, Bates GP. Formation of polyglutamine inclusions in a wide range of non-CNS tissues in the HdhQ150 knock-in mouse model of Huntington's disease. PLoS One. 2009 Nov 30;4(11):e8025.

61. Maywood ES, Fraenkel E, McAllister CJ, Wood N, Reddy AB, Hastings MH, Morton AJ. Disruption of peripheral circadian timekeeping in a mouse model of Huntington's disease and its restoration by temporally scheduled feeding. J Neurosci. 2010 Jul 28;30(30):10199-204. 
62. Wood NI, Sawiak SJ, Buonincontri G, Niu Y, Kane AD, Carpenter TA, Giussani DA, Morton AJ. Direct evidence of progressive cardiac dysfunction in a transgenic mouse model of Huntington's disease. J Huntingtons Dis. 2012;1(1):57-64.

63. Magnusson-Lind A, Davidsson M, Silajdžić E, Hansen C, McCourt AC, Tabrizi SJ, Björkqvist M. Skeletal muscle atrophy in R6/2 mice - altered circulating skeletal muscle markers and gene expression profile changes. J Huntingtons Dis. 2014;3(1):13-24.

64. Larson E, Fyfe I, Morton AJ, Monckton DG. Age-, tissue- and length-dependent bidirectional somatic $\mathrm{CAG} \cdot \mathrm{CTG}$ repeat instability in an allelic series of $\mathrm{R} 6 / 2$ Huntington disease mice. Neurobiol Dis. 2015;76:98-111.

65. McCourt AC, Jakobsson L, Larsson S, Holm C, Piel S, Elmér E, Björkqvist M. White Adipose Tissue Browning in the R6/2 Mouse Model of Huntington's Disease. PLoS One. 2016 Aug 3;11(8):e0159870. doi: 10.1371/journal.pone.0159870. eCollection 2016.

66. Trushina E, Dyer RB, Badger JD, Ure D, Eide L, Tran DD, Vrieze BT, Legendre-Guillemin V, McPherson PS, Mandavilli BS, Van Houten B, Zeitlin S, McNiven M, Aebersold R, Hayden M, Parisi JE, Seeberg E, Dragatsis I, Doyle K, Bender A, Chacko C, McMurray CT. Mutant huntingtin impairs axonal trafficking in mammalian neurons in vivo and in vitro. Mol. Cell Biol. 2004; 24 (18): 8195-09.

67. Stack EC, Dedeoglu A, Smith KM, Cormier K, Kubilus JK, Bogdanov M, Matson WR, Yang L, Jenkins BG, Luthi-Carter R, Kowall NW, Hersch SM, Beal MF, Ferrante RJ. Neuroprotective effects of synaptic modulation in Huntington's disease R6/2 mice. J Neurosci. 2007; 27 (47):12908-15.

68. Milnerwood AJ, Raymond LA. Corticostriatal synaptic function in mouse models of Huntington's disease: early effects of huntingtin repeat length and protein load. J Physiol. 200; 585 (Pt3):81731.

69. Browne SE, Ferrante RJ, Beal MF. Oxidative stress in Huntington's disease. Brain Pathol 1999; 9 (1): 147-163.

70. Calabrese V, Scapagnini G, Giuffrida Stella AM, Bates TE, Clark JB.. Mitochondrial involvement in brain function and dysfunction: relevance to aging, neurodegenerative disorders and longevity. Neurochem. Res, 2001; 26 (6):739-764.

71. Acevedo-Torres K, Berríos L, Rosario N, Dufault V, Skatchkov S, Eaton MJ, Torres-Ramos CA, and Ayala-Torres S. Mitochondrial DNA damage is a hallmark of chemically induced and the R6/2 transgenic model of Huntington's disease. DNA Repair (Amst). 2009; 8 (1):126-36.

72. Kim J, Moody JP, Edgerly CK, Bordiuk OL, Cormier K, Smith K, Beal MF, Ferrante RJ. Mitochondrial loss, dysfunction and altered dynamics in Huntington's disease. Hum. Mol. Genet. $2010 ; ; 19(20): 3919-3935$.

73. Squitieri F, Falleni A, Cannella M, Orobello S, Fulceri F, Lenzi P, Fornai F. Abnormal morphology of peripheral cell tissues from patients with Huntington disease. J. Neural. Transm. 2010; 117 (1):77-83.

74. Costa V, Giacomello M, Hudec R, Lopreiato R, Ermak G, Lim D, Malorni W, Davies KJ, Carafoli E, Scorrano L. Mitochondrial fission and cristae disruption increase the response of cell models of Huntington's disease to apoptotic stimuli. EMBO Mol. Med. 2010; 2 (12):487-489.

75. Wang H, Lim PJ, Karbowski M, Monteiro MJ. Effects of overexpression of huntingtin proteins on mitochondrial integrity. Hum. Mol. Genet. 2009; 18 (4):737-752.

76. Rosas HD, Koroshetz WJ, Chen YI, Skeuse C, Vangel M, Cudkowicz ME, Caplan K, Marek K, Seidman LJ, Makris N, Jenkins BG, Goldstein JM. Evidence for more widespread cerebral pathology in early HD: an MRI-based morphometric analysis. Neurology. 2003; 60 (10):1615-20.

77. Kassubek J, Gaus W, Landwehrmeyer GB. Evidence for more widespread cerebral pathology in early HD: an MRI-based morphometric analysis. Neurology. 2004; 62 (3):523-524. 
78. Aylward EH, Brandt J, Codori AM, Mangus RS, Barta PE, Harris GJ. Reduced basal ganglia volume associated with the gene for Huntington's disease in asymptomatic at-risk persons. Neurology. 1994; 44(5):823-8.

79. Harris GJ, Codori AM, Lewis RF, Schmidt E, Bedi A, Brandt J. Reduced basal ganglia blood flow and volume in pre-symptomatic, gene-tested persons at-risk for Huntington's disease. Brain. 1999; 122 (Pt9):1667-1678.

80. Majid DS, Aron AR, Thompson W, Sheldon S, Hamza S, Stoffers D, Holland D, Goldstein J, Corey-Bloom J, Dale AM. Basal ganglia atrophy in prodromal Huntington's disease is detectable over one year using automated segmentation. Mov Disord. 2011;26(14):2544-51.

81. van den Bogaard SJ, Dumas EM, Acharya TP, Johnson H, Langbehn DR, Scahill RI, Tabrizi SJ, van Buchem MA, van der Grond J, Roos RA, TRACK-HD Investigator Group. Early atrophy of pallidum and accumbens nucleus in Huntington's disease. J Neurol. 2011258 (3):412-20.

82. van den Bogaard SJ, Dumas EM, Hart EP, Milles J, Reilmann R, Stout JC, Craufurd D, Gibbard CR, Tabrizi SJ, van Buchem MA, van der Grond J and Roos RAC. Magnetization transfer imaging in premanifest and manifest huntington disease: a 2-year follow-up. AJNR Am J Neuroradiol. 2013. 34 (2):317-22.

83. Tabrizi SJ, Scahill RI, Owen G, Durr A, Leavitt BR, Roos RA, Borowsky B, Landwehrmeyer B, Frost C, Johnson H, Craufurd D, Reilmann R, Stout JC, Langbehn DR TRACK-HD Investigators. Predictors of phenotypic progression and disease onset in premanifest and early-stage Huntington's disease in the TRACK-HD study: analysis of 36-month observational data. Lancet Neurol. 2013. 12 (7):637-49.

84. Albin RL. Selective neurodegeneration in Huntington's disease. Ann Neurol. 199538 (6):835836.

85. Gómez-Tortosa E, MacDonald ME, Friend JC, Taylor SA, Weiler LJ, Cupples LA, Srinidhi J, Gusella JF, Bird ED, Vonsattel JP, Myers RH. Quantitative neuropathological changes in presymptomatic Huntington's disease. Ann Neurol. 2001; 49 (1):29-34. 


\section{Figure 1 Electronmicroscopy shows morphology of novel ENNIs}

The electronmicrographs show the classic electron luscent NNIs (A, black asterisk) that are located in the nucleus $(\mathrm{N})$. The electron dense nENNIs (white asterisks) are found in both nonmyelinated (B) and myelinated processes (C, D). Novel ENNIs are round or oval and fill the axon or dendrite, pushing organelles (in this case mitochondria) to the periphery of the process $(\mathrm{C}, \mathrm{D}$, arows). Scale bar: $1 \mu \mathrm{m}$.

\section{Figure 2 Electronmicroscopy shows Progressive 'maturation' of novel ENNIs}

The electronmicrographs show that the density of nENNIs increases with age. The image in A is taken from an animal aged 22 weeks, and those in B-D from an animal aged 104 weeks. Novel ENNIs in the older animals display a core that is more electron-dense than the surrounding inclusion material, exhibiting a multi-layered appearance (white asterisks in B-D).

Figure 3 Progressive appearance and different localisation of inclusions in Q250 and Q550 mice

Immunohistochemical staining for MW8 (that recognises aggregated Htt) reveals the progressive accumulation of inclusions with increased age $(8,20,22$ weeks of age for Q250 mice, and 8, 20 and 104 weeks of age for Q550 mice) in the hippocampus of Q250 (A-C) and Q550 R6/2 mice (D-F). Both NIIs and ENNIs are seen in progressively greater abundance. NIIs are intranuclear and located in the pyramidal cell layer of CA1 of the hippocampus (Py) in Q250 6/2 mice at 8 weeks of age $\left(\mathrm{A}^{\prime}\right)$. Their abundance increases with age $\left(\mathrm{B}^{\prime}\right.$ and $\left.\mathrm{C}^{\prime}\right)$. Extracellular inclusions appear in regions in which there are few cell bodies, such as the lacunosum moleculare (LMol) and stratum radiatum $(\mathrm{Rad})$. They are present at 8 weeks and commonly seen by 20 weeks of age (B, B', C and C', arrowheads). By contrast, the Q550 mice have no intranuclear inclusions within 
Py (D-F) but extranuclear inclusions can be seen in the LMol and Rad as early as 8 weeks of age (D', arrowheads). Extranuclear inclusions increase in size and number with age in the Q550 R6/2 mice (E, E', F and F', arrowheads).

Figure 4 Progressive appearance of ubiquitin- and MW8- positive (Htt) ENNIs is age and stage dependent.

The cartoons show R6/2 brains colour coded for ubiquitin or MW8 staining. Intensity of shading is proportional to the intensity of inclusion staining. This revealed a progressive and regiondependent increase in nENNIs with age. The ontogenic pattern was similar in both lines of mice, but was delayed in mice with longer CAG repeats. There was a major difference in the intensity of staining in the oldest mice with ubiquitin and MW8 that was not present at 52 weeks of age, when nEENIs stained with similar intensity with both antibodies.

Figure 5: Neurodegenerative profiles in mice with super long CAG repeats seen with electronmicroscopy

Electron mictrographs show abnormal and neurodegenerative profiles from brains of super-long CAG repeat mice (104 weeks of age). Electron microscopy revealed abnormalities in the brain tissue of R6/2 mice with super-long CAG repeats. An inclusion completely filling a process (white asterisk) pushes organelles to the periphery (A, arrows). Abnormal mitochondria (B, arrowheads), vacuoles in processes (C, black asterisks) and anomalies in the myelin sheath $(\mathrm{C}$, arrows) were seen in all sections. Degenerating neurons are also clearly evident (D, E and F; arrows). Scale bar: $1 \mu \mathrm{m}$. 
Figure 6: Different profiles of atrophy are seen different brain regions of Q250 and Q550 R6/2 mice

Volume measurements reveal atrophy at end stage in Q250 mice in $\mathrm{CPu}(\mathrm{A})$. Progressive atrophy was measured in Q550 mice (B), starting as early as 12 weeks of age. Cortical volume measurements reveal atrophy in S1BF by 20 weeks of age in Q250 mice (C). Progressive atrophy was observed in Q550 mice, starting as early as 22 weeks of age in S1BF (D). Cortical volume measurements reveal atrophy in M1 by 20 weeks of age in Q250 mice (E). Progressive atrophy was observed in Q550 mice by 52 weeks of age (F). (open bars; WT; closed bars: R6/2 mice; * $\mathrm{p}<0.05 ; * * \mathrm{p}<0.01 ; * * * \mathrm{p}<0.001$, ANOVA with post-hoc Bonferroni analysis).

$\mathrm{CPu}$ caudate putamen

$\mathrm{S} 1 \mathrm{BF}=$ somatosensory cortex

$\mathrm{M} 1=$ primary motor cortex

Figure 7: Different profiles of cell loss in the caudate-putamen of Q250 and Q550 R6/2 mice.

Histograms of unbiased optical fractionator estimates of the number of Nissl stained neurons in the caudate putamen of R6/2 (closed bars) and age-matched WT mice (open bars) at different stages of disease progression. The number of neurons in caudate putamen declined in Q250 R6/2 mice (A) at end stage only. By contrast, neuron loss in Q550 mice (B), first became evident at 22 weeks of age and declined progressively until end stage

$* \mathrm{p}<0.05 ; * * \mathrm{p}<0.01 ; * * * \mathrm{p}<0.001$ (ANOVA with post-hoc Bonferroni analysis) 
Figure 8: Different profiles of cell loss in the somatosensory cortex of Q250 mice and Q550 R6/2 mice

Unbiased optical fractionator estimates of the number of neurons in somatosensory cortex (S1BF) of R6/2 mice and age-matched WT mice revealed a progressive neuron loss in Q550 R6/2 mice, whereas in Q250 R6/2 mice neuron loss occurred only at end stage (A-F). Notably, both lines of R6/2 mice displayed neuron loss in lamina V only (C and D). Lamina IV and VI did not display neuron loss at end stage so we did not quantify the earlier stages (ND). (open bars; WT; closed bars: R6/2 mice; * $\mathrm{p}<0.05 ; * * \mathrm{p}<0.01 ; * * * \mathrm{p}<0.001$, ANOVA with post-hoc Bonferroni analysis).

Figure 9: Different profiles of cell loss in the motor cortex of Q250 mice and Q550 R6/2 mice Unbiased optical fractionator estimates of the number of neurons in motor cortex (M1) occurred at end stage for both sets of R6/2 mice. However, in the Q250 cell loss was only observed in lamina IV (A) whereas in the Q550, cell loss was observed in laminae IV, V and VI (B, D, F). Lamina V and VI did not display neuron loss at end stage in the Q250 so we did not quantify neuron loss at the earlier stages in these mice (C and F; ND). (open bars; WT; closed bars: R6/2 mice; * $\mathrm{p}<0.05 ; * * \mathrm{p}<0.01 ; * * * \mathrm{p}<0.001$, ANOVA with post-hoc Bonferroni analysis). 
Figure 1
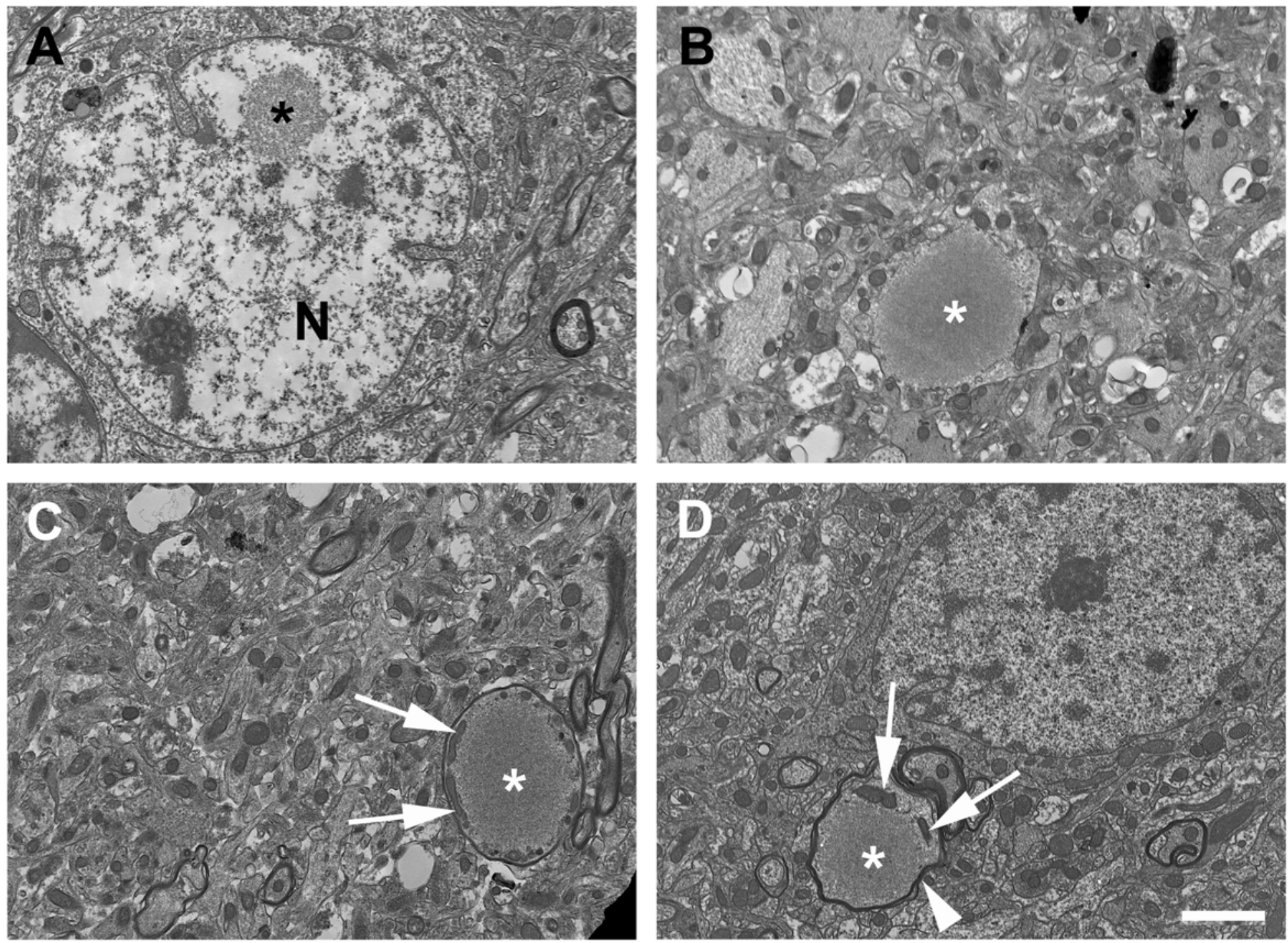
Figure 2
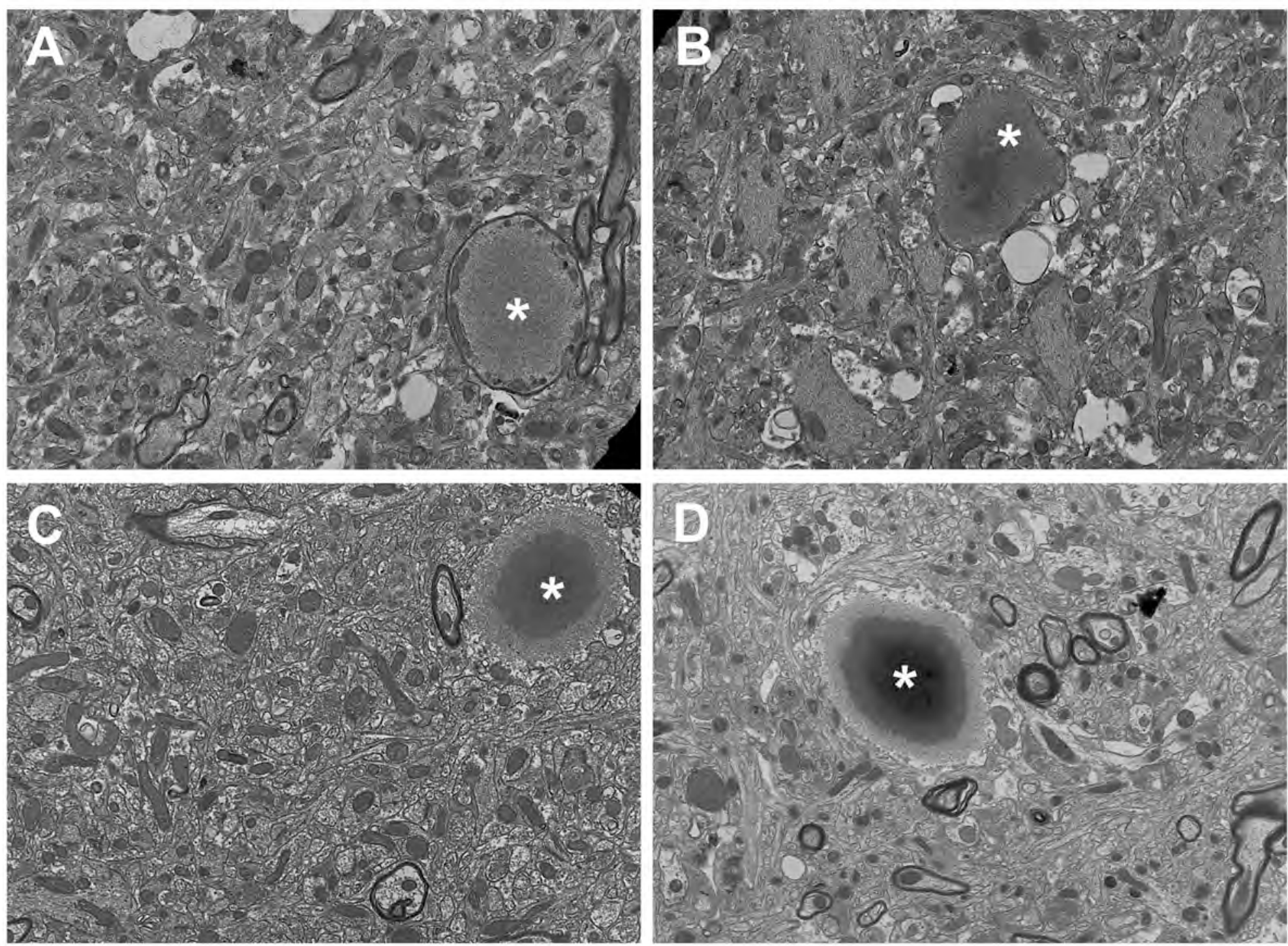
Figure 3
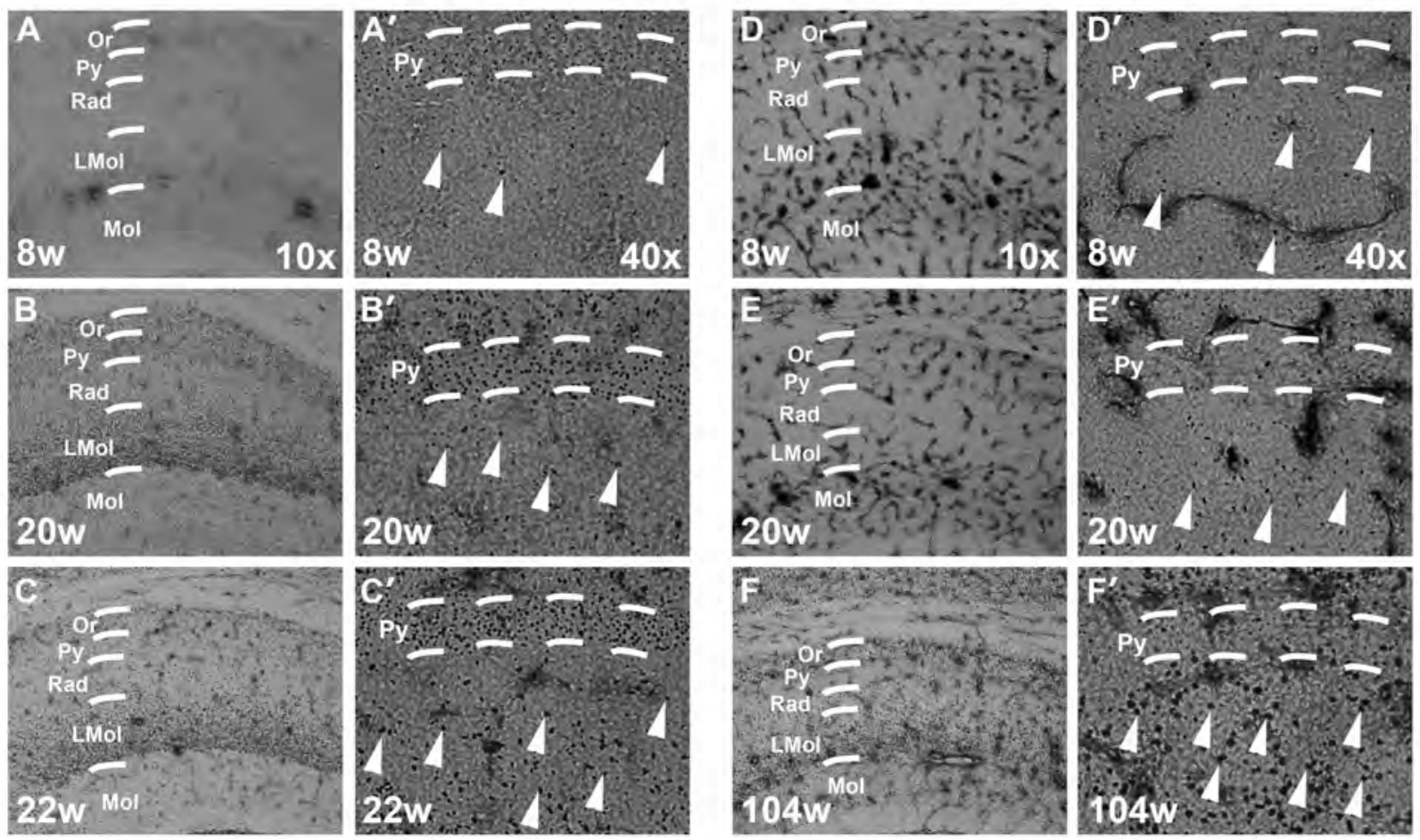
Figure 4

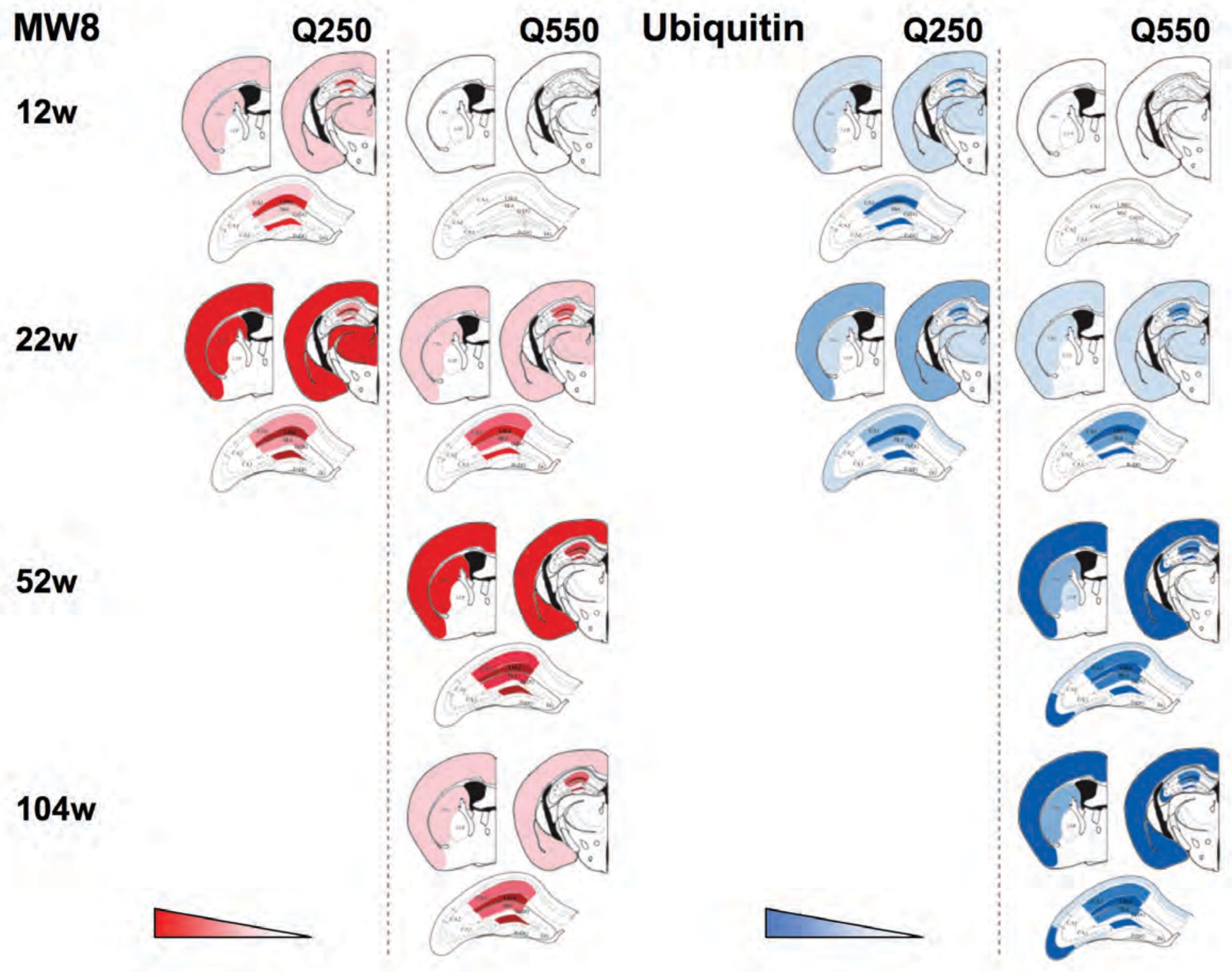


Figure 5
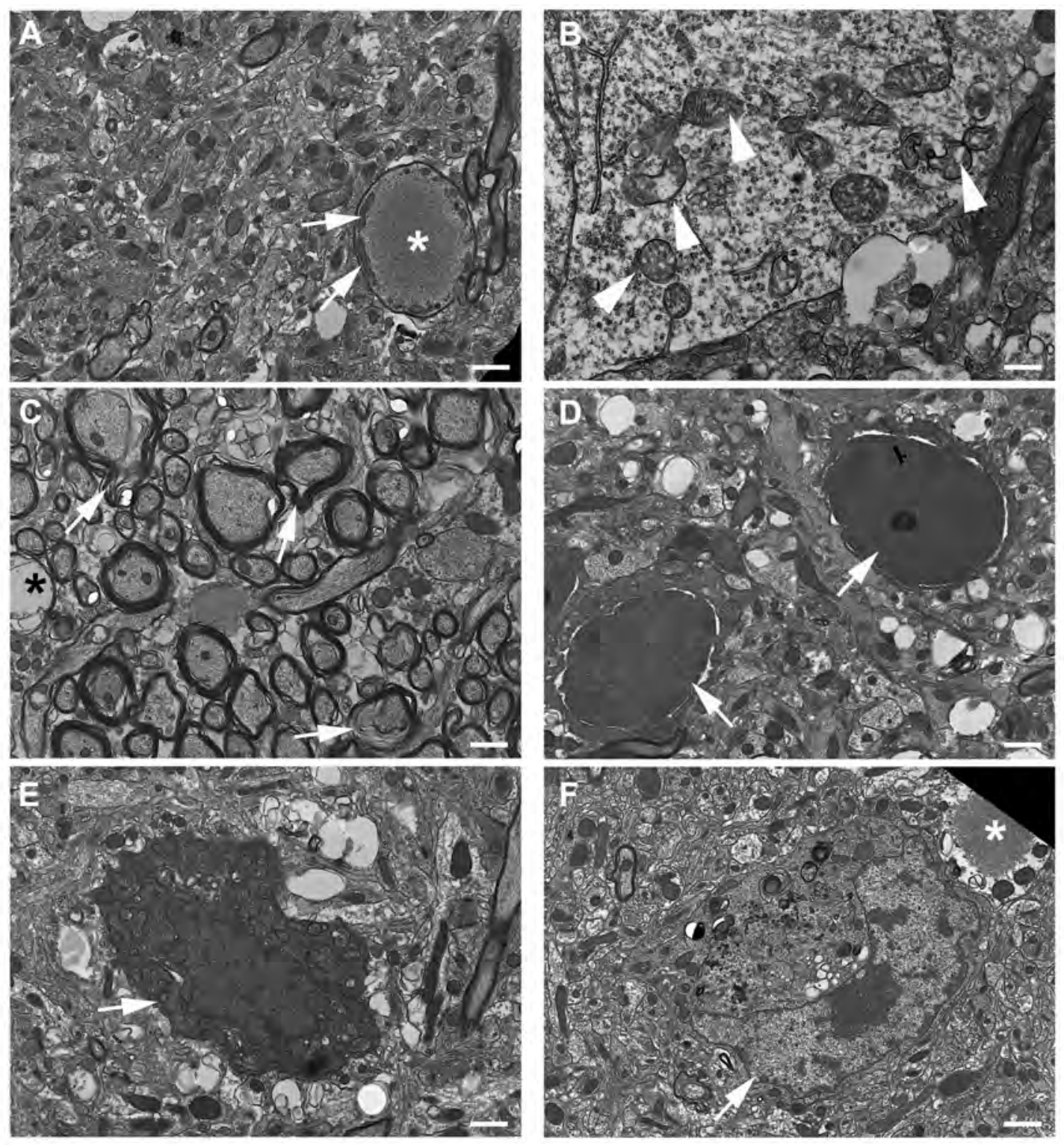
Figure 6

A

B

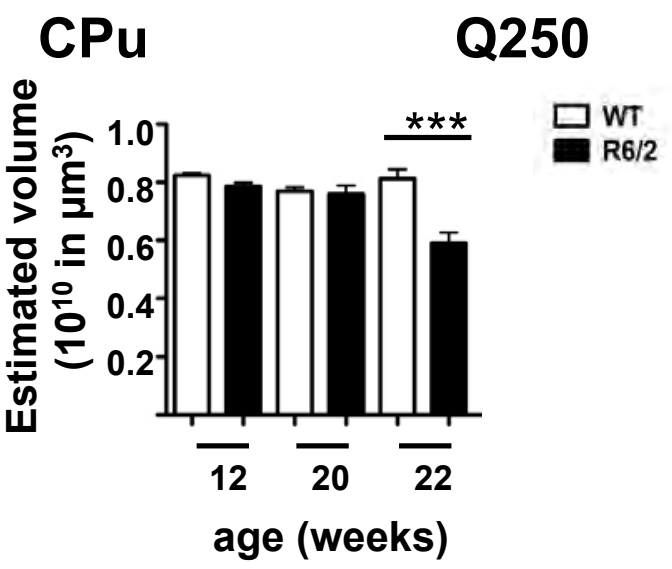

C

\section{S1BF Q250}

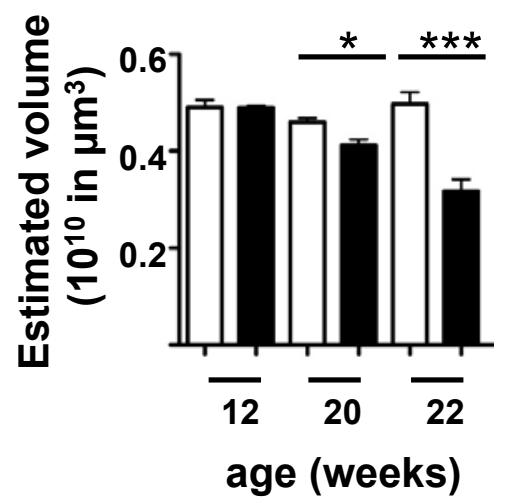

E

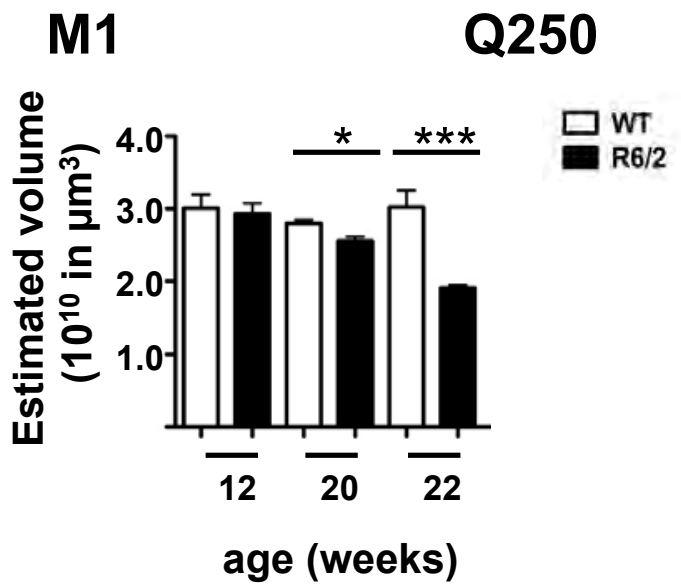

D
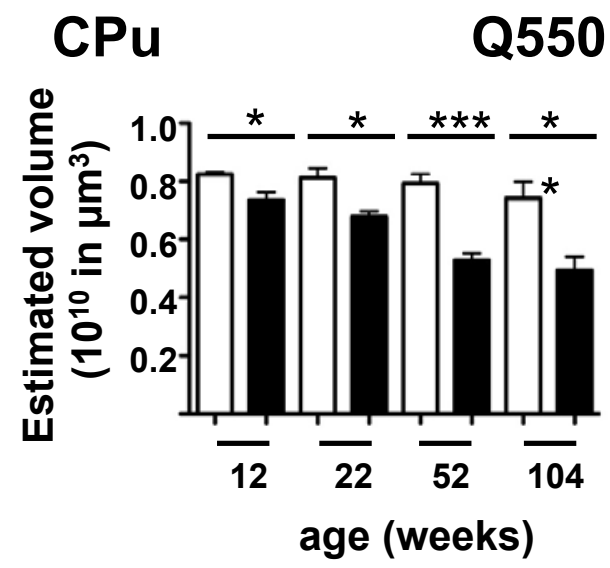

S1BF

Q550

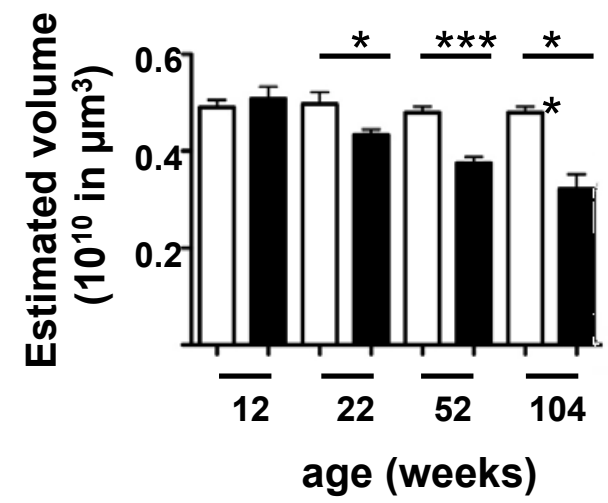

$\mathbf{F}$

Q550

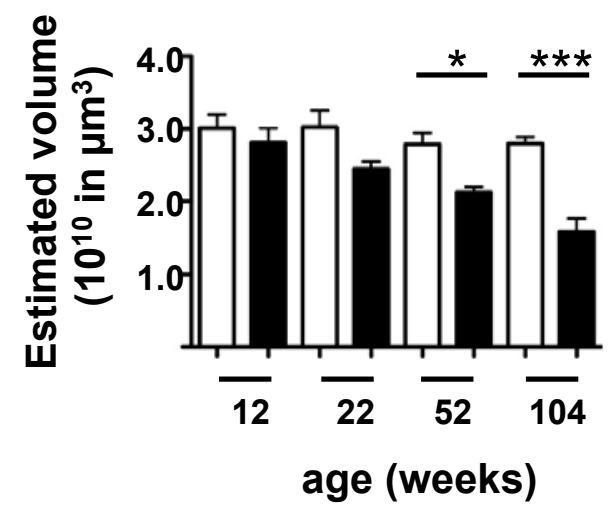


Figure 7

A

Q250

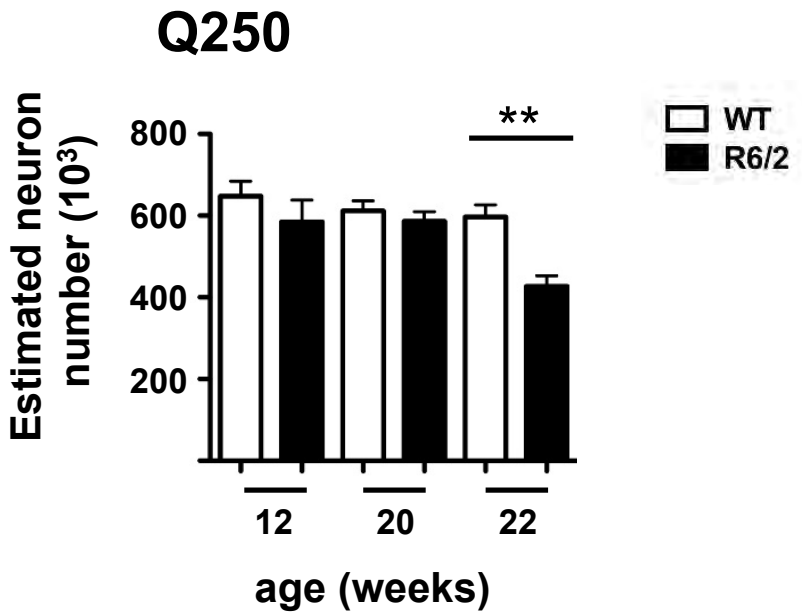

B

Q550

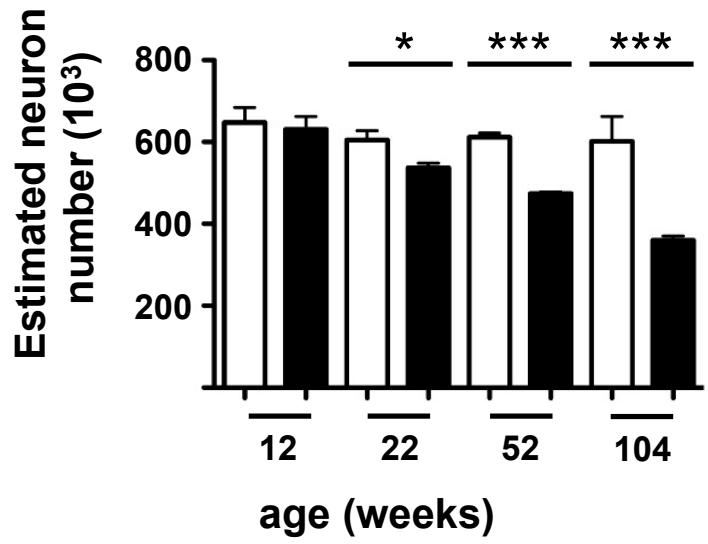


Figure 8

A

B

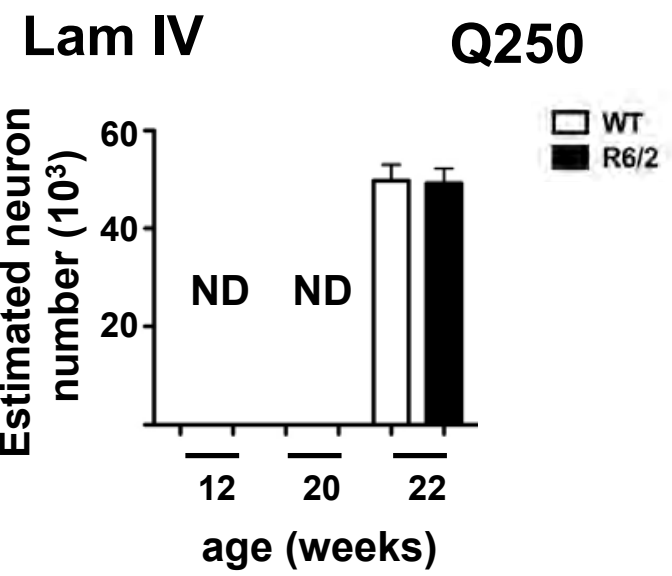

D

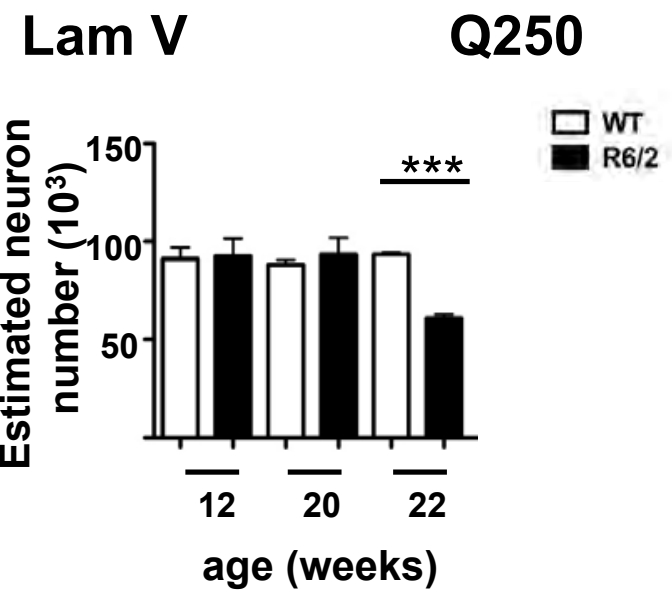

E

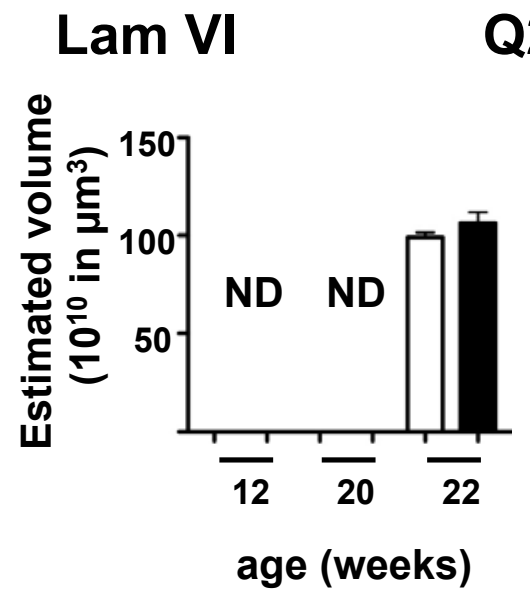

\section{Lam VI}

Q550

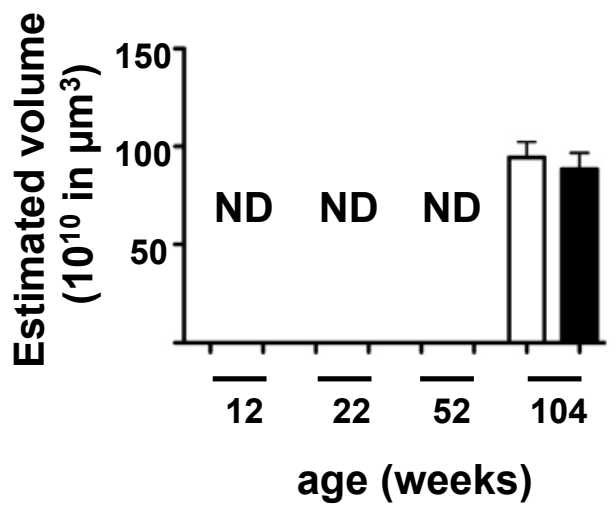


Figure 9

A

B

Lam IV

Q250

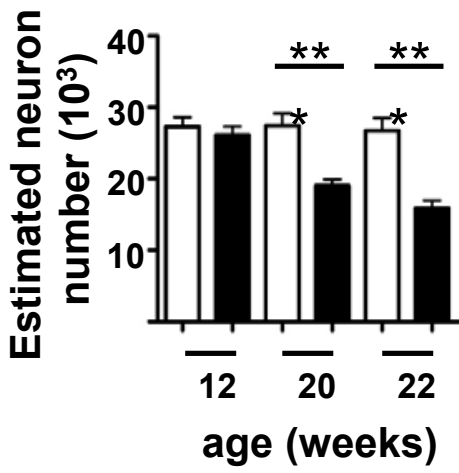

C

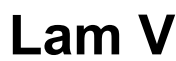

Q250

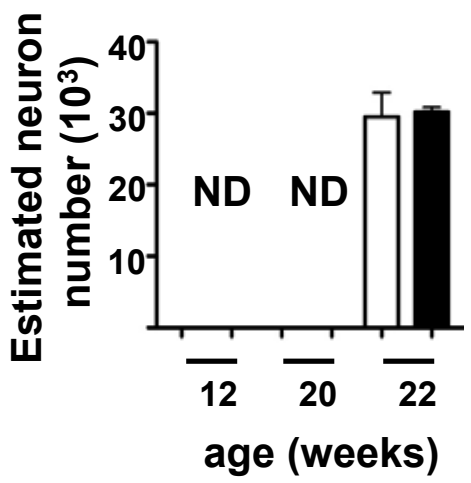

E

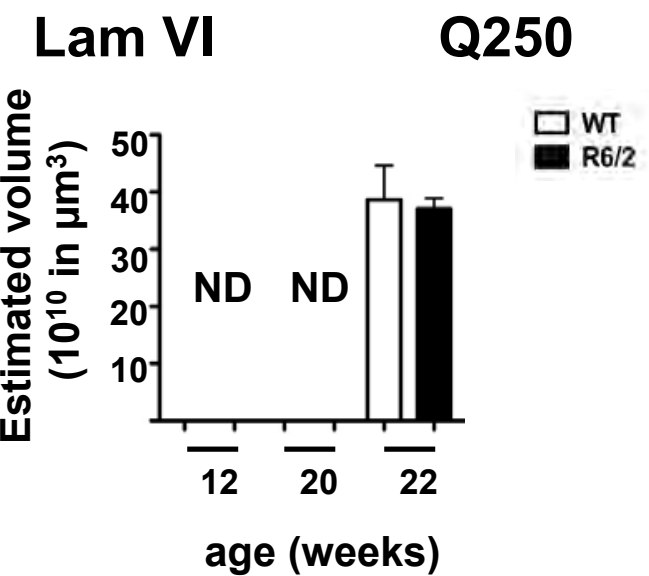

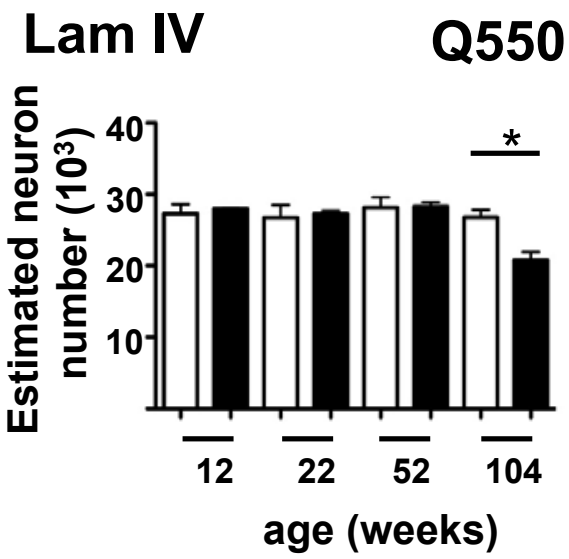

D

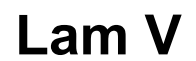

Q550

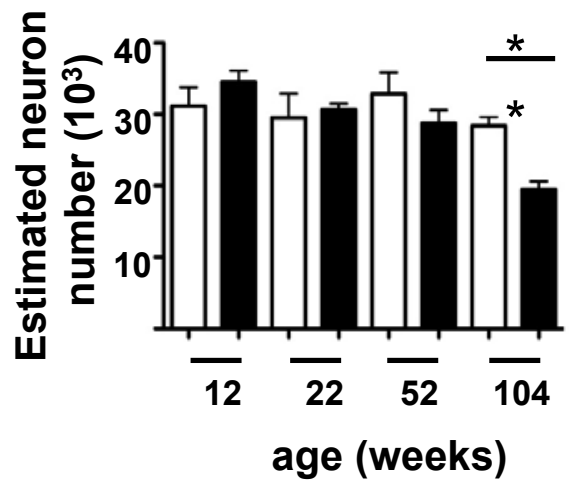

F
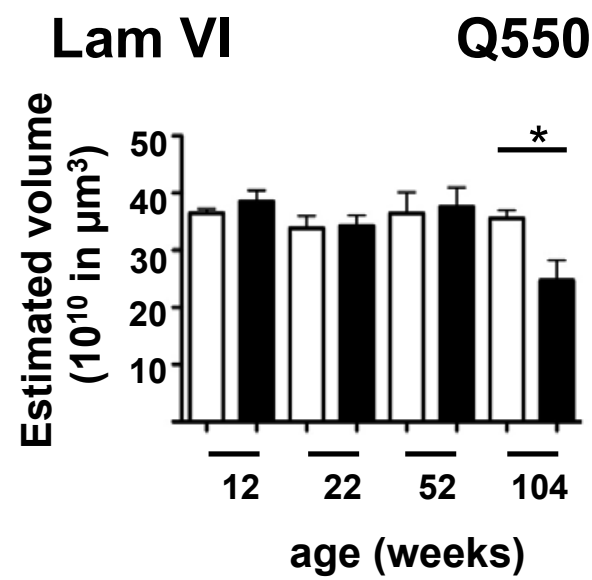